\title{
PERAN CITRA MEREKDALAM MEMEDIASI PENGARUH KUALITAS PRODUK TERHADAP NIAT BELI
}

\author{
Ida Bagus Putu Suandayana ${ }^{1}$ \\ Putu Yudi Setiawan'2
}

\author{
${ }^{1,2}$ Fakultas Ekonomi dan Bisnis Universitas Udayana (Unud), Bali, Indonesia \\ E-mail:suanyana@gmail.com
}

\begin{abstract}
ABSTRAK
Tujuan penelitian ini adalah untuk mengetahui pengaruh kualitas produk terhadap citra merek pada latop Apple macbook, untuk mengetahui pengaruh kualitas produk dan citra merek terhadap niat beli pada produk laptop Apple macbook, dan untuk mengetahui peran citra merek dalam memediasi pengaruh kualitas produk terhadap niat beli. Populasi penelitian ini adalah seluruh responden yang berdomisili di Kota Denpasar yang mempunyai niat untuk membeli laptop Apple macbook. Sampel sebanyak 112 orang responden dari seluruh wilayah Kota Denpasar. Data di analisis menggunakan Metode PLS (Partial Least Square). Hasil penelitian menunjukkan bahwa pengaruh kualitas produk dan citra merek secara parsial berpengaruh positif dan signifikan terhadap niat beli pada laptop Apple macbook, dan kualitas produk secara parsial berpengaruh positif dan signifikan terhadap citra merek pada laptop Apple macbook. Hasil juga menunjukkan bahwa citra merek mampu memediasi pengaruh kualitas produk terhadap niat beli.
\end{abstract}

Kata Kunci: kualitas produk, citra merek, niat beli

\begin{abstract}
The purpose of this study is to determine the effect of product quality on brand image on Apple macbook latop, to know the effect of product quality and brand image on purchase intention on Apple Macbook laptop product, and to know the role of brand image in mediating the effect of product quality on buying intention. The population of this study is all respondents who are domiciled in Denpasar City who have the intention to buy Apple Macbook laptops. A sample of 112 respondents from all parts of Denpasar City. The data was analyzed using the PLS Method (Partial Least Square). The results show that the effect of product quality and brand image partially have a positive and significant effect on purchase intention on Apple Macbook laptops, and product quality partially positively and significantly influence to the brand image on Apple Macbook laptops. The results also show that brand image is able to mediate the influence of product quality on purchase intention.
\end{abstract}

Keywords: product quality, brand image, purchase intention 


\section{PENDAHULUAN}

Sejalan dengan kemajuan dalam bidang ekonomi, maka pengembangan dunia usaha juga mengalami pertumbuhan dan kemajuan yang pesat. Semua ini dibuktikan dengan bermunculannya perusahaan-perusahaan baru. Semuanya berusaha memproduksi barang dan jasa untuk memenuhi kebutuhan dan keinginan konsumen yang semakin meningkat. Hal ini akan mengakibatkan terjadinya persaingan yang ketat pada setiap industri yang ada. Jika suatu perusahaan ingin memenangkan persaingan maka setiap perusahaan harus memiliki keunggulan produk,termasuk perusahaan yang memproduksi portable computeratau sering disebut laptop di Indonesia yang saat ini hampir semua lapisan masyarakat menggunakannya.

Semua hal tersebut tidak mudah untuk dicapai, karena saat ini merupakan zaman dimana terdapat persaingan dalam dunia perusahaan yang sangat ketat dan kompetitif. Persaingan pasar dapat diukur ketika suatu produk dan jasa berhasil dipasarkan makaselanjutnya akan terjadi persaingan dalam penjualan dengan perusahaan-perusahaanlain. Untuk memaksimalkan penjualan dalam persaingan bisnis yang semakin ketat, para pengusaha berkompetisi untuk memasarkan produk dan jasanya dalam meningkatkan penjualannya untuk mempertahankan keberlangsungan bisnisnya.

Komputer merupakan salah satu produk yang mengalami perkembangan yang cukup pesat. Awal mula komputer yang sebenarnya dibentuk oleh seorang Professor Matematika Inggris, bernama Charles Babbage pada Tahun 1791-1871. Perkembangan sejarah kemunculan komputer melalui lima generasi, dimana 
generasi pertama pada Tahun 1946-1959, generasi kedua Tahun 1959-1964, generasi ketiga Tahun 1964-1970, generasi keempat Tahun 1970-1990, dan generasi kelima pada Tahun 1990-an (Suyanto, 2015).

Menurut Prasetyo (2015), menyatakan bahwa komputer pada generasi pertama memiliki keterbatasan yang sangat serius. Dalam melaksanakan operasi internalnya, komputer ini masih menggunakan tabung hampa (vacum tube) yang berukuran cukup besar dan menghasilkan panas. Kemampuannya melakukan operasi internal juga masih sangat terbatas. Selanjutnya, komputer generasi kedua sudah tidak menggunakan tabung hampa, tetapi menggunakan transistor yang memiliki ukuran jauh lebih kecil dibanding tabung hampa, dengan kemampuan sangat besar dan harga lebih murah. Penggunaan transistor ini telah berhasil melakukan penyempurnaan secara drastik dalam hal biaya, kecepatan operasi, keandalan dan ukuran komputer. Berbeda dengan komputer generasi ketiga yang memiliki ukuran yang lebih kecil, namun kemampuan dan kecepatan operasinya jauh lebih tinggi. Perkembangan komputer generasi keempat memiliki kemampuan dan kecepatan operasinya jauh lebih cepat dibandingkan komputer generasi sebelumnya. Pada perkembangan komputer generasi kelima masih bertahan sampai sekarang dengan penyempurnaan-penyempurnaan yang semakin baik.

Awal generasi perkembangan komputer diciptakan dalam bentuk yang besar,namun seiring berjalannya waktu komputer diciptakan dengan ukuran yang minimalis dengan spesifikasi dan fungsi yang hebat yang sering kita sebut 
komputerjinjing atau Laptop. Laptop sudah mulai menjadi pembicaraan serius dikalangan para produsen dan komputer pada awal Tahun 1070-an (Dama, 2016).

Seiring perkembangan zaman globalisasi ini produk laptop sudah sekian banyak, deretan laptop yang sedang sering digunakan juga sudah sangat banyak. Indonesia merupakan salah satu Negara yang terdapat banyak merek-merek laptop yang menawarkan kualitas terbaik dan keunikan tersendiri. Beberapa merek laptop yang beredar di pasaran Indonesiaantara lain, yaitu Asus,Acer,Toshiba,Apple,Lenovo,SonyVaio,HP,Dell dan sebagainya. Setiap merek laptop memiliki keunggulan masing-masing,seperti misalnya harga lebih murah,tetapi memiliki kualitas produk yangbaik dan ada pula yang memiliki kualitas terbaik dengan harga yang relatif lebih mahal. Konsumen yang mengikuti trend masa kini dalam memutuskan pembelian produk, mereka akan lebih memilih produk yang berkualitas unggul dengan citra merek yang yang jauh lebih baik.

Perusahaan Apple adalah perusahaan yang memproduksi perangkat komputer yang sering dikenal dengan nama Apple Macbook. Apple Macbook merupakan komputer jinjing yang memiliki keunggulan berbeda dengan komputer jinjing lainnya, seperti misalnya dari segi tampilan produk,kualitas produk, dan operasi sistem yang digunakan pada Apple Macbook. Fenomena ini dapat dilihat dari kondisi persaingan dalam produksi laptop. Hal tersebut dibuktikan dengan penguasaan pangsa pasar (market share) pada produk laptop merek Apple Macbook pada Tahun 2014-2015 yang disajikan pada Tabel 1 sebagai berikut: 
E-Jurnal Manajemen, Vol. 8, No. 1, 2019: 7371 - 7398 
Tabel 1.

Data Pengiriman dan Market Share Laptop di Indonesia Tahun 2014-2015

\begin{tabular}{|c|c|c|c|c|c|}
\hline $\begin{array}{l}\text { Merek } \\
\text { Laptop }\end{array}$ & $\begin{array}{c}\text { Pengiriman } \\
\text { Kuartal } 2 \\
(\text { 2014) }\end{array}$ & $\begin{array}{c}\text { Market } \\
\text { Share } \\
\text { Kuartal } 2 \\
(2014)\end{array}$ & $\begin{array}{c}\text { Pengiriman } \\
\text { Kuartal } 2 \\
(\text { 2015) }\end{array}$ & $\begin{array}{c}\text { Market } \\
\text { Share } \\
\text { Kuartal } \\
(2015) \\
\end{array}$ & $\begin{array}{c}\text { Pertumbuhan } \\
\text { Kuartal Tahun } \\
\text { (2014/2015) }\end{array}$ \\
\hline 1. Lenovo & 14,535 & $19,4 \%$ & 13,444 & $20,3 \%$ & $-7,5 \%$ \\
\hline 2. HP & 13,675 & $18,2 \%$ & 12,253 & $18,5 \%$ & $-10,4 \%$ \\
\hline Dell & 10,466 & $14,0 \%$ & 9,560 & $14,5 \%$ & $-8,7 \%$ \\
\hline 4. Apple & 4,423 & $5,9 \%$ & 5,163 & $7,8 \%$ & $16,1 \%$ \\
\hline Acer & 5,932 & $7,9 \%$ & 4,334 & $6,6 \%$ & $-28,9 \%$ \\
\hline 6. ASUS & 4,693 & $6,3 \%$ & 4,330 & $6,5 \%$ & $-7,7 \%$ \\
\hline Lainnya & 21,274 & $28,4 \%$ & 17,082 & $25,8 \%$ & $-19,7 \%$ \\
\hline Total & 74,998 & $100,0 \%$ & 66,140 & $100,0 \%$ & $-11,8 \%$ \\
\hline
\end{tabular}

Sumber:Winpoin.com, 2015

Berdasarkan Tabel 1 dapat dilihat bahwa laptop merek Apple Macbook mengalami peningkatanmarket share yang cukup signifikan dari Tahun 2014 hingga Tahun 2015 untuk kategori produk laptop merek Apple Macbook, yaitu pada Tahun 2014 sebesar 5,9\% naik menjadi 7,8 \% dan mengalami pertumbuhan pada kuartal 2 Tahun 2014 dan 2015 sebesar 16,1\% . Sedangkan pesaing utamanya Lenovo, pada Tahun yang sama mengalami kenaikan yang signifikan. Lenovo mengalami peningkatan market share dari Tahun 2014 sebesar 19,4\% naik menjadi 20,3\% pada Tahun 2015,tetapi Lenovo mengalami penurunan pertumbuhan pada kuartal 2 pada Tahun 2014 dan 2015 sebesar -7,5\%.

Peningkatanpertumbuhan market share pada laptop Apple Macbook dari Tahun 2014 hingga 2015diduga dipengaruhi oleh meningkatnya niat beli konsumen untuk melakukan pembelian laptop Apple Macbook.Niat beli adalah tahap konsumen dalam membentuk pilihan mereka diantara beberapa merek yang tergabung dalam perangkat pilihan, kemudian pada akhirnya melakukan suatu pembelian pada suatu alternatif yang paling disukainya atau proses yang dilalui konsumen untuk membeli suatu barang atau jasa yang didasari oleh bermacam 
pertimbangan (Annafik dan Rahardjo, 2012).Niat beli dapat digunakan untuk menganalisis perilaku konsumen, sebelum melakukan pembelian konsumen akan mencari informasi tentang suatu produk. Kemudian konsumen akan melakukan penilaian terhadap produk berdasarkan informasi yang mereka miliki, selanjutnya konsumen akan melakukan perbandingan produk dan melakukan evaluasi serta membuat suatu keputusan pembelian.

Salah satu faktor yang dapat mempengaruhi niat beli konsumen adalah citra merek. Citra merek mempunyai sifat khas, dan sifat khas inilah yang membedakan produk yang satu berbeda dengan produk yang lainnya, walaupun sejenis. Permintaan akan sebuah produk barang yang semakin berkualitas membuat perusahaan yang bergerak diberbagai bidang usaha berlomba-lomba meningkatkan dan mempertahankan citra merekproduk yang mereka miliki. Citra merekadalah seperangkat keyakinan, ide, kesan yang dimiliki seorang terhadap suatu merek (Kotler, 2002:101). Menurut Adil (2012)fungsi utama citra merekadalah untuk menjawab pertanyaan tentang bagaimana konsumen memilih diantara merek alternatif setelah melakukan pengambilan informasi.Hasil penelitian dari Putra (2014) menyatakan bahwa citra merek memiliki pengaruh positif dan signifikan terhadap niat beli, yang menyatakan bahwa citra mereksemakin ditingkatkan maka dapat meningkatkan niat membeli. Penelitian lainnya dari Kiswalini (2014) menyatakan bahwa citra merekberpengaruh positif dan signifikan terhadap niat beli,menyatakan apabila citra produk baik maka konsumen akan melakukan pembelian terhadap produk tersebut. 
Penelitian dari Chi et al.(2009) menyatakan bahwa kualitas dari pengalaman pembelian mereka, akibatnya merek, loyalitas dan preferensi merek akan meningkatkan niat pembelian. Penelitian lainya dari Rizkynanda (2013) menyatakan kualitas berpengaruh positif dan signifikan terhadap niat beli, menyatakan bahwa semakin tinggi yang dirasakan oleh konsumen, maka semakin tinggi pula kesediaan konsumen tersebut untuk akhirnya niat untuk membeli.

Penelitian ini difokuskan pada masyarakat Kota Denpasar yang ingin membeli dan memakai produk Apple khususnya laptop Apple Macbook dalam kehidupan sehari-hari. Penelitian ini dilakukan atas dasar adanya berbagai latar belakang hidup,sifat,kultur,kebiasaan,sosial, dan tingkat ekonomi hal ini secara tidak langsung akan mempengaruhi pola kehidupan sehari-hari termasuk juga dalam menentukan pilihan untuk membeli produk laptop Apple Macbook.

Konsep produk menyatakan bahwa konsumen akan lebih menyukai produkproduk yang menawarkan fitur-fitur yang paling bermutu,berprestasi atau inovatif. Menurut Kotler dan Amstrong (2010:248) produk adalah segala sesuatu yang dapat ditawarkan ke pasar untuk mendapatkan perhatian,dibeli,digunakan,atau dikonsumsi yang dapat memuaskan keinginan dan kebutuhan. Kesimpulan dari beberapa definisi adalah produk merupakan seperangkat atribut yang dapat ditawarkan kepada pasar untuk dikonsumsi agar dapat memuaskan dan memenuhi kebutuhankonsumen.

Menurut Kotler dan Amstrong (2010:27) kualitas produk adalah kemampuan suatu produk untuk melakukan fungsi-fungsinya.Menurut Tjiptono (2005:68) indikator kualitas produk antara lain meliputi: 1) Keistimewaan 
tambahan merupakan karakteristik sekunder yang melengkapi manfaat dasar suatu produk. Fitur ini bersifat pilihan bagi konsumen. Fitur idealnya bisa digunakan untuk meningkatkan kualitas suatu produk yang mana tidak dimiliki produk pesaing. 2) Keandalan merupakan peluang suatu produk bebas dari kegagalan saat menjalankan fungsinya. Misalnya pengawasan kualitas dan desain,standar karakteristik operasional. 3) Daya tahan bahan berkaitan dengan usia produk, yaitu jumlah pemakaian suatu produk sebelum produk itu digantikan atau rusak. 4) Estetika menyangkut tampilan produk yang bisa membuat konsumen tertarik. Ini sering kali dilakukan dalam bentuk desain produk atau kemasannya. 5) Kualitas yang dipersepsikan menyangkut penilaian konsumen terhadap citra,merek atau iklan. Produk-produk bermerek terkenal biasanya dipersepsikan lebih berkualitas dibandingkan dengan merek-merek yang tidak didengar.

Menurut Laksana (2008:88-89) mendefinisikan kualitas adalah jaminan terbaik kita atas kesetiaan pelanggan, pertahanan terkuat kita dalam menghadapi persaingan asing dan satu-satunya jalan menuju pertumbuhan dan pendapatan yang langgeng.

Merek merupakan identitas dari barang atau jasa. Sebuah merek yang terkenal dan terpercaya merupakan asset yang tidak ternilai. Merek berkembang menjadi sumber asset terbesar dan merupakan faktor penting dalam kegiatan pemasaran perusahaan. Keahlian yang paling unik dari pemasar professional adalah kemampuannya untuk menciptakan, memelihara dan melindungi serta meningkatkan merek. Chinomona (2016) mendefinisikan citra merek sebagai rangkaian atau penjumlah total dari asosiasi merek yang diadakan dalam memori 
konsumen yang menyebabkan persepsi tentang merek sementara. Citra merek membuat konsumen dapat mengenal suatu produk, mengevaluasi kualitas dari produk tersebut, serta dapat menyebabkan risiko pembelian yang rendah. Konsumen pada umumnya lebih menyukai merek yang terkenal meskipun terkadang harga yang ditawarkan lebih mahal.

Citra merek adalah persepsi konsumen yang diasosiasikan dengan merek tertentu. Citra ini mungkin didasarkan pada persepsi rasional atau emosional, yang berarti bahwa konsumen dapat memiliki persepsi terhadap merek sebagai sesuatu yang praktis dan berkualitas serta persepsi bahwa merek tersebut menambahkan semacam status kepada konsumen yang menggunakannya. Belic et al., (2012).

Wu dan Wen (2014) citra merek dapat dibagi menjadi tiga konstruk, yang bersifat fungsional, simbolis dan eksperiensial, dan rinci yaitu : 1) Gambar Fungsional: Fungsi produk dapat membantu konsumen mengatasi masalah konsumen dan mencegah masalah potensial. 2) Citra simbolis: Merek dapat memuaskan keinginan dalam diri konsumen seperti meningkatkan nilai diri,status sosial,pengakuan diri,dll. 3) Citra eksperiensial: Merek dapat memuaskan keanekaragaman konsumen dan rangsangan sehingga dapat memberikan mereka pengalaman menyenangkan.

Kiswalini (2014) mengemukakan indikator dari citra merek antara lain: 1) Modern adalah memiliki model yang tidak ketinggalan jaman. 2) Gentle Hars adalah mempunyai tekstur produk halus atau tidak kasar. 3) Popular adalah akrab di benak konsumen. 4) Kekuatan adalah dapat digunakan dengan baik dan bermanfaat. 5) Keunikan adalah memiliki desain dan keaslian komponen 
pendukung atau bentuk yang berbeda. 6) Favorable adalah kemudahan untuk dikenali konsumen

Niat (intention) adalah penilaian subjektif tentang apa yang akan dimiliki oleh konsumen dimasa yang akan datang (Enggel, 2001 dalam Hartini 2012). Niat beli merupakan kemungkinan bahwa konsumen akan merencanakan atau bersedia untuk membeli produk atau jasa tertentu di masa depan Wu et al. (2011). Dai et al. (2014) menyatakan bahwa konsumen akan cenderung mengandalkan berbagai sumber informasi untuk memastikan kualitas dari suatu produk. Niat beli merupakan penentuan dari pembelian untuk melakukan tindakan seperti membeli suatu produk atau jasa (Mowen 2007:43). Niat beli seringkali digunakan untuk menganalisa perilaku konsumen. Sebelum melakukan pembelian,konsumen akan mencari informasi tentang produk yang akan menjadi pertimbangan. Prosesproses niat beli menurut Semuel dan Wijaya (2008) yaitu : 1) Pengenalan produk adalah pengenalan tentang produk yang ditawarkan sesuai dengan kebutuhan calon konsumen. 2) Rangsangan adalah suatu pertanda yang menyebabkan seseorang untuk ingin bertindak mempromosikan barang atau jasa. 3) Pencarian informasi adalah pengumpulan sesuatu informasi yang bersumber dari dalam diri konsumen atau luar diri konsumen. 4) Pemilihan alternatif adalah konsumen mengalami pilihan yang sulit yang membuat dilematis untuk memilih suatu produk. 4) Merealisasikan pembelian adalah konsumen bertindak sebagai eksekutor untuk melakukan pembelian terhadap produk atau jasa.

Noerchoidah (2013) dalam penelitiannya yang berjudul Analisis Pengaruh Harga, Kualitas Produk dan Iklan terhadap Citra merek dan Keputusan Pembelian 
Ida Bagus Putu Suandayana, Peran Citra Merek...

menyatakan bahwa variabel kualitas produk dapat mempengaruhi secara signifikan terhadap citra merek. Penelitian ini ditunjukkan nilai CR sebesar 4.568 dengan probabilitas sebesar 0.000 . Oleh karena nilai probabilitas $<0.05$ maka dapat disimpulkan bahwa variabel kualitas produk berpengaruh terhadap citra merek.

Hasil penelitian tersebut sejalan dengan penelitian yang dilakukan oleh Nurdianto dan Yuniati (2013) yang mendapatkan hasil pengujian, kualitas produk berpengaruh positif dan signifikan terhadap citra sepeda motor Honda. Hasil ini menunjukkan semakin baik kualitas produk akan semakin meningkatkan citra produk tersebut pada konsumen.

Penelitian yang dilakukan oleh Nuraini (2015) yang berjudul Pengaruh Celebrity Endorse dan Kualitas Produk terhadap Keputusan Pembelian melalui Citra Merek juga mendapatkan hasil yang sama yaitu, kualitas produk berpengaruh secara langsung terhadap citra merek.

$\mathrm{H}_{1}$ : Kualitas produk berpengaruh positif dan signifikan terhadap citra merek.

Penelitian yang dilakukan oleh Indrayani (2013) memperlihatkan bahwa variabel kualitas produk memiliki pengaruh yang positif dan signifikan terhadap niat beli produk handphone Samsung Galaxy di Kota Denpasar. Penelitian yang dilakukan oleh Budiningtyas dkk. (2010) yang menyimpulkan bahwa kualitas produk adalah salah satu dari berbagai faktor yang mempengaruhi niat beli.

$\mathrm{H}_{2}$ : Kualitas produk berpengaruh positif dan signifikan terhadap niat beli.

Citra merek (brand image) merupakan representasi dari keseluruhan persepsi terhadap merek dan dibentuk dari informasi dan pengalaman masa lalu 
terhadap merek itu (Pradipta, 2012). Menurut Evelina dkk. (2012) citra merek (brand image) merupakan representasi dari keseluruhan persepsi terhadap merek dan dibentuk dari informasi dan pengalaman masa lalu terhadap merek itu. Dalam penelitian yang dilakukan oleh Haerudin (2010) memperlihatkan bahwa citra merek memiliki pengaruh yang signifikan terhadap niat beli konsumen. Hasil yang sama juga disebutkan oleh penelitian Yu et al. (2013) yang juga mengemukakan bahwa citra merekmemiliki dampak yang positif terhadap niat membeli konsumen.Penelitian oleh Maunaza (2012) dan Shah et al. (2012) mengatakan bahwa citra merek memiliki pengaruh positif yang signifikan terhadap niat beli konsumen. Selain itu, pernyataan tersebut didukung juga oleh hasil penelitian Nan \& Bih (2007) yang menunjukkan adanya pengaruh citra merek terhadap niat beli konsumen.

$\mathrm{H}_{3}$ : Citra merek berpengaruh positif dan signifikan terhadap niat beli.

Pada $\mathrm{H}_{2}$ diajukan hipotesis bahwa variabel kualitas produk memiliki pengaruh yang positif terhadap niat beli. Pada $\mathrm{H}_{1}$ dan $\mathrm{H}_{3}$ berpendapat bahwa kualitas produk berpengaruh positif terhadap citra merek dan variabel citra merek berpengaruh positif pula terhadap niat beli. Berdasarkan hipotesis-hipotesis tersebut, terdapat indikasi pengaruh langsung yang positif dari variabel kualitas produk terhadap niat beli melalui citra merek. Ruth et al. (2002) menyatakan bahwa sikap terhadap merek tertentu dipengaruhi oleh kesan atau citra dari merek tersebut. Park et al. (1986); dan Juhairi et al. (2006) menyatakan citra merek memiliki pengaruh langsung pada volume penjualan produk. Aaker dan Keller (1990); Putra dan Sulistyawati (2015); dam Kirwadi (2016) meyatakan bahwa 
semakin baik citra merek maka akan semakin tinggi niat beli konsumen, maka peneliti merumuskan hipotesis sebagai berikut:

$\mathrm{H}_{4}$ : Citra merek memediasi pengaruh kualitas produk terhadap niat beli.

\section{METODE PENELITIAN}

Penelitian ini mengambil lokasi di Kota Denpasar. Kota Denpasar dipilih karena merupakan pusat kota dengan tingkat kepadatan penduduk terbesar dibandingkan dengan kota lain di Provinsi Bali. Menurut Badan Pusat Statistik Tahun 2015 Denpasar memiliki kepadatan penduduk terbesar di antara kota yang ada di Provinsi Bali yaitu sebesar 6891.5 juta jiwa, ditambah tingginya daya beli masyarakat dengan jumlah pasar potensial yang sangat besar, maka sangat mudah untuk menemukan responden yang sesuai dengan kategori yang diteliti.

Variabel bebas dalam penelitian ini adalah kualitas produk (X1). Variabel mediasi dalam penelitian ini adalahcitra merek $\left(\mathrm{Y}_{1}\right)$. Variabel terikat dalam penelitian ini adalahniat beli $\left(\mathrm{Y}_{2}\right)$.

Tabel 2.

Rangkuman Definisi Operasional Variabel Penelitian

\begin{tabular}{|c|c|c|}
\hline Variabel & Indikator & Referensi \\
\hline Kualitas Produk & $\begin{array}{l}\text { 1.Karakteristik tambahan untuk menjadi pembeda } \\
\text { (X1.1) } \\
\text { 2.Keandalan (X1.2) } \\
\text { 3.Daya Tahan Bahan (X1.3) } \\
\text { 4.Estetika (X1.4) } \\
\text { 5.Kualitas yang dipersepsikan (X1.5) }\end{array}$ & Tjiptono (2005:68) \\
\hline Citra Merek & $\begin{array}{l}\text { 1.Penampilan fisik produk (Y1.1) } \\
\text { 2.Kualitas Produk (Y1.2) } \\
\text { 3.Citra merek yang dimiliki (Y1.3) } \\
\text { 4.Keunggulan produk (Y1.4) } \\
\text { 5.Kemampuan merek (Y1.5) } \\
\text { 6.Kemudahan merek (Y1.6) }\end{array}$ & $\begin{array}{ll}\text { Keller (2008: } & 58) \\
\text { Kiswalini (2014) } & \end{array}$ \\
\hline Niat Beli & $\begin{array}{l}\text { 1.Pengenalan produk (Y2.1) } \\
\text { 2.Rangsangan (Y2.2) } \\
\text { 3.Pencarian Informasi (Y2.3) } \\
\text { 4.Pemilihan alternatif (Y2.4) } \\
\text { 5.Merealisasikan pembelian (Y2.5) }\end{array}$ & $\begin{array}{llr}\text { Berman } & (2001: & 48) \\
\text { Samuel } & \text { dan } & \text { Wijaya } \\
(2008) & & \end{array}$ \\
\hline
\end{tabular}


E-Jurnal Manajemen, Vol. 8, No. 1, 2019: 7371 - 7398

Sumber: Data diolah, 2018 
Populasi dalam penelitian ini adalah seluruh responden yang berdomisili di Kota Denpasar yang mempunyai niat untuk membeli laptop Apple Macbook, sehingga jumlah populasi tidak dapat ditentukan secara pasti (infinite).

Roscoe dalam Sekaran(2003) mengemukakan ukuran sampel yang baik adalah 5 - 10 kali jumlah variabel atau indikator dalam penelitian. Penelitian ini menggunakan 16 indikator sehingga dengan menggunakan estimasi berdasarkan jumlah parameter diperoleh ukuran sampel sebesar $70-140$ responden. Jumlah dari sampel responden yang akan diuji diperoleh dari hasil perhitungan sebagai berikut :

$$
\begin{array}{r}
\text { Jumlah Responden }=16 \text { indikator } \mathrm{x} 7 \\
=112 \text { responden }
\end{array}
$$

Dipilihnya 112 responden karena dalam penelitian ini menggunakan metode PLS (Partial Least Square), dimana dalam metode ini harus menggunakan minimal 100 sampel. Jadi, dipilihnya 112 responden ini merupakan sudah sesuai dengan kriteria yang ditentukan.

Teknik penentuan sampel yang digunakan pada penelitian ini adalah non probability sampling, yaitu teknik pengambilan sampel yang tidak memberi peluang/kesempatan sama bagi setiap unsur anggota populasi untuk dipilih menjadi sampel (Sugiyono,2014:120). Teknik non probability sampling yang digunakan dalam penelitian ini adalah purposive sampling.

Instrumen penelitian yang digunakan berupa kuesioner terdiri dari pertanyaan terbuka dan pernyataan tertutup. Pertanyaan terbuka terdiri dari identitas diri, umur, jenis pekerjaan dan pernyataan tertutup terdiri dari pernyataan-pernyataan yang telah disediakan dan dibatasi sesuai kondisi. Metode 
pengumpulan data disebarkan secara langsung kepada responden untuk diisi sendiri atau ditanyakan melalui wawancara.

Penelitian ini menggunakan teknik analisis data yaitu analisis SEM (Structural equation modeling) berbasis component atau variance yaitu PLS (Partial Least Square). Menurut Ghozali (2011:18), PLS merupakan factor inderteminancy metode analisis yang kuat oleh karena tidak mengasumsikan data harus dengan pengukuran skala tertentu, jumlah sampel kecil, dapat digunakan untuk mengkonfirmasi teori, dan membantu untuk mendapatkan nilai variabel laten untuk tujuan prediksi.

\section{HASIL PENELITIAN DAN PEMBAHASAN}

Karakteristik responden dapat dilihat berdasarkan pengelompokkan jenis kelamin, jenis kelamin laki-laki mendominasi dalam penelitian ini dengan presentase sebesar 52,68 persen.Berdasarkan usia, responden yang memiliki usia 22-26 tahun mendominasi dalam penelitian ini dengan persentase sebesar 33,04 persen. Berdasarkan pekerjaan, responden yang memiliki pekerjaan pelajar/mahasiswa mendominasidalam penelitianini dengan persentase sebesar 43,75 persen. Berdasarkan pendidikan, responden yang memiliki pendidikan S1 mendominasi dalam penelitian ini dengan persentase sebesar 40,18 persen. Berdasarkan penghasilan, responden yang memiliki penghasilan sebesar 3-4 juta mendominasi dalam peelitian ini dengan persentase sebesar 34,82 persen.

Convergent validity dengan indikator refleksif dapat dilihat dari korelasi antara skor indikator dengan skor variabelnya. Indikator individu dianggap reliabel apabila memiliki nilai korelasi diatas 0,70 . Namun pada riset tahap 
pengembangan skala, loading 0,50 sampai 0,60 masih dapat diterima (Ghozali, 2011:40). Hasil korelasi antara indikator dengan variabelnya dapat dilihat pada Tabel 3 sebagai berikut :

Tabel 3.

Outer Loadings

\begin{tabular}{lccr}
\hline & Original Sample $(\mathbf{O})$ & T Statistics $(\mid \mathbf{O} /$ STDEV $\mid)$ & P Values \\
\hline X1.1 <- Kualitas Produk & 0.897 & 43.077 & 0.000 \\
X1.2 <- Kualitas Produk & 0.929 & 63.298 & 0.000 \\
X1.3 <- Kualitas Produk & $\mathbf{0 . 9 4 0}$ & 77.696 & 0.000 \\
X1.4 <- Kualitas Produk & 0.914 & 53.237 & 0.000 \\
X1.5 <- Kualitas Produk & 0.921 & 53.572 & 0.000 \\
X2.1 <- Citra Merek & 0.864 & 32.453 & 0.000 \\
X2.2 <- Citra Merek & 0.787 & 22.725 & 0.000 \\
X2.3 <- Citra Merek & 0.934 & 68.088 & 0.000 \\
X2.4 <- Citra Merek & $\mathbf{0 . 9 3 8}$ & 71.849 & 0.000 \\
X2.5 <- Citra Merek & 0.915 & 57.128 & 0.000 \\
X2.6 <- Citra Merek & 0.917 & 55.753 & 0.000 \\
Y1.1 <- Niat Beli & 0.917 & 55.521 & 0.000 \\
Y1.2 <- Niat Beli & 0.968 & 121.031 & 0.000 \\
Y1.3 <- Niat Beli & $\mathbf{0 . 9 6 9}$ & 111.440 & 0.000 \\
Y1.4 <- Niat Beli & 0.955 & 83.537 & 0.000 \\
Y1.5 <- Niat Beli & 0.965 & 98.610 & 0.000 \\
\hline Sumber Data diolah, 2018 & & &
\end{tabular}

Berdasarkan Tabel 3, hasil output telah memenuhi convergent validity karena factor loading berada di atas 0,50. Dari variabel kualitas produk (X1) indikator X1.3 memiliki nilai outer loadings tertinggi dibandingkan indikator lain yaitu 0,940 , maka dapat dijelaskan bahwa indikator tersebutdapat merefleksikan variabel kualitas produk(X1). Dari variabel Citra merek (X2) indikator X2.4 memiliki nilai outer loadings tertinggi dibandingkan indikator lain yaitu 0,938, maka dapat dijelaskan bahwa indikator tersebutdapat merefleksikan variabel Citra merek(Y). Dari variabel niat beli (Y) indicator Y1.3 memiliki nilai outer loadings tertinggi dibandingkan indikator lain yaitu 0,969, maka dapat dijelaskan bahwa indikator tersebutdapat merefleksikan variabel niat beli (Y). 
Model Struktural (Inner Model) bertujuan untuk untuk memprediksi hubungan antar variabel laten. Dalam PLS prediksi hubungan ini dapat dilihat dari nilai $R$ Square $\left(\mathrm{R}^{2}\right)$ untuk setiap variabel laten endogen sebagai kekuatan prediksi dari model struktural. Penilaian model struktural juga dapat dilakukan dengan $\mathrm{Q}^{2}$ predictive relevance, yang juga disebut dengan predictive sample reuse.

Tabel 4.

R-square

\begin{tabular}{lc}
\hline & R Square \\
\hline Citra Merek & 0.849 \\
Niat Beli & 0.766 \\
\hline
\end{tabular}

Sumber: Data diolah, 2018

Selanjutnya akan dihitung koefisien determinasi total adalah sebagai berikut:

$$
\begin{aligned}
\mathrm{Q}^{2} \quad & =1-\left(1-\mathrm{R}_{1}{ }^{2}\right)\left(1-\mathrm{R}_{2}^{2}\right) \ldots \ldots \\
& =1-(1-0,849)(1-0,766) \\
& =1-(0,151)(0,234) \\
& =1-0,035=0,965
\end{aligned}
$$

Besaran $Q^{2}$ memiliki nilai dengan rentang $0<0,965<1$, dimana semakin mendekati 1 berarti model baik. Pada perhitungan nilai koefisien determinasi total didapatkan sebesar 0,965 maka kesimpulannya adalah bahwa 96,5 \% variabel citra merek dan kualitas produk memiliki pengaruh terhadap niat beli pada produk laptop apple macbook di kota denpasar, sisanya sebesar 3,5\% di pengaruhi oleh variable lain yang tidak dimasukan dalam penelitian 
Hasil pengujian pengaruh langsung dijelaskan pada tabel 5 di bawah ini:

Tabel 5.

Pengaruh Langsung

\begin{tabular}{cccc}
\hline & Original Sample $(\mathbf{O})$ & T Statistics $(\mid \mathbf{O} /$ STDEV $\mid)$ & P Values \\
\hline Citra Merek -> Niat Beli & 0.267 & 2.112 & 0.035 \\
Kualitas Produk -> Citra Merek & 0.922 & 50.097 & 0.000 \\
Kualitas Produk -> Niat Beli & 0.623 & 5.404 & 0.000 \\
\hline Sumber: Data diolah, 2018 & & &
\end{tabular}

Berdasarkan hasil analisis PLS menunjukkan arah masing-masing variabel bebas terhadap variabel terikatnya. Hasil tersebut dapat diuraikan sebagai bahwa pengaruh kualitas produk terhadap niat beli sebesar $+0,623$, menunjukkan bahwa kualitas produk berpengaruh positif terhadap niat beli produk laptop apple macbook di kota denpasar , apabila kualitas produk meningkat maka niat beli akan meningkat sebesar 0,623.

Pengaruh kualitas produk terhadap citra mereksebesar 0,922, menunjukkan bahwa kualitas produk berpengaruh positif terhadap citra merek terhadap produk laptop apple macbook di kota denpasar, apabila kualitas produk meningkat maka citra merek akan meningkat sebesar 0,922 .

Pengaruh citra merek terhadap niat beli sebesar 0,267, menunjukkan bahwa citra merek berpengaruh positif terhadap niat beli produk laptop apple macbook di kota denpasar, apabila citra merek produk apple macbook di masyarakat meningkat maka niat beli masyarakatakan mengalami peningkatan sebesar 0,267 .

Hasil pengujian pengaruh tidak langsung dijelaskan dalam tabel 6 di bawah ini: 
Tabel 6.

Pengaruh Tidak Langsung

\begin{tabular}{cccc}
\hline & Original Sample (O) & $\begin{array}{c}\text { T Statistics } \\
(\mid \mathbf{O} \text { STDEV })\end{array}$ & P Values \\
\hline Kualitas Produk -> Niat Beli & 0.246 & 2.096 & 0.037 \\
\hline Sumber: Data & & &
\end{tabular}

Sumber:Data diolah, 2018

Berdasarkan Tabel 6. diketahui bahwa nilai signifikansi p-value sebesar $0,037 \leq 0,05$, maka $\mathrm{H}_{0}$ ditolak. Ini berarti bahwa kualitas produk berpengaruh signifikan terhadap niat beli produk laptop apple macbook di kota denpasar dengan dimediasi oleh citra merek.

Hasil pengujian mediasi dengan metode VAF telah memenuhi beberapa persyaratan yaitu, pertama, pengaruh langsung (a) variabel kualitas produk (X1) terhadap niat beli (Y) tanpa melibatkan variabel mediasi citra merek (X2) pada model, telah ditemukan signifikan. Kedua, setelah variabel citra merek (X2) dimasukkan ke dalam model, maka pengaruh tidak langsung (b x c) ditemukan signifikan. Jalur b dan c juga signifikan. Ketiga, menghitung Variance Accounted For (VAF) dengan rumus:

$$
\begin{aligned}
\mathrm{VAF} & =(0,922 \times 0,267) /(0,870+0,922 \times 0,267) \\
& =0,246 / 1,116 \\
& =0,221 \text { atau } 22,1 \text { persen }
\end{aligned}
$$

Karena nilai VAF (22,1 persen) berada di rentang 20 persen hingga 80 persen, maka dapat dikategorikan sebagai pemediasi parsial (partial mediation).

Pengujian hipotesis pada pengaruh kualitas produkterhadap citra merek menunjukkan bahwa kualitas produksecara positif berpengaruh signifikan terhadap citra merek produk laptop apple macbook di Kota Denpasar. Ditunjukkan dengan koefisien sebesar 0,922 dan signifikan pada alpha 5 persen ( $p$-value $0,000 \leq 0,05)$. Artinya, semakin meningkat kualitas produkyang dimiliki 
produk laptop apple macbook di Kota Denpasar . Maka citra merek produk laptop apple macbook di Kota Denpasar akan semakin meningkat. Berdasarkan hal tersebut maka hipotesis pengaruh kualitas produkberpengaruh positif dan signifikan terhadap citra merek produk laptop apple macbook di kota denpasar diterima. Hasil penelitian tersebut sejalan dengan penelitian yang dilakukan oleh Nurdianto dan Yuniati (2013) yang mendapatkan hasil pengujian, kualitas produk berpengaruh positif dan signifikan terhadap citra sepeda motor Honda. Hasil ini menunjukkan semakin baik kualitas produk akan semakin meningkatkan citra produk tersebut pada konsumen. Penelitian yang dilakukan oleh Nuraini (2015) yang berjudul Pengaruh Celebrity Endorse dan Kualitas Produk terhadap Keputusan Pembelian melalui Citra Merek juga mendapatkan hasil yang sama yaitu, kualitas produk berpengaruh secara langsung terhadap citra merek.

Pengujian hipotesis pada pengaruh kualitas produkterhadap niat beli menunjukkan bahwa kualitas produksecara positif berpengaruh signifikan terhadap niat beli produk laptop apple macbook di Kota Denpasar . Ditunjukkan dengan koefisien sebesar 0,623 dan signifikan pada alpha 5 persen ( $p$-value 0,000 $\leq 0,05)$. Artinya, semakin meningkat kualitas produkyang dimiliki produk laptop apple macbook di Kota Denpasar maka niat beli produk laptop apple macbook di kota denpasar akan semakin meningkat. Berdasarkan hal tersebut maka hipotesis pengaruh kualitas produkberpengaruh positif dan signifikan terhadap niat beli produk laptop apple macbook di Kota Denpasar diterima. Hasil Penelitian ini sesuai dengan penelitian yang dilakukan oleh Indrayani (2013) memperlihatkan bahwa variabel kualitas produk memiliki pengaruh yang positif dan signifikan 
terhadap niat beli produk handphone Samsung Galaxy di Kota Denpasar. Penelitian yang dilakukan oleh Budiningtyas dkk. (2010) yang menyimpulkan bahwa kualitas produk adalah salah satu dari berbagai faktor yang mempengaruhi niat beli

Pengujian hipotesis pada pengaruh Citra merekterhadap niat beli menunjukkan bahwa Citra mereksecara positif berpengaruh signifikan terhadap niat beli produk laptop apple macbook di Kota Denpasar. Ditunjukkan dengan koefisien sebesar 0,267 dan signifikan pada alpha 5 persen ( $p$-value $0,035 \leq 0,05$ ). Artinya, semakin meningkat Citra merekyang dimiliki produk laptop apple macbook di Kota Denpasarmaka niat beli produk laptop apple macbook di kota denpasarjuga akan semakin tinggi. Berdasarkan hal tersebut maka hipotesis pengaruh Citra merekberpengaruh positif dan signifikan terhadap niat beli produk laptop apple macbook di Kota Denpasarditerima. Hasil penelitian ini sesuai dengan penelitian yang dilakukan oleh Haerudin (2010) memperlihatkan bahwa citra merek memiliki pengaruh yang signifikan terhadap niat beli konsumen. Hasil yang sama juga disebutkan oleh penelitian Yu et al. (2013) yang juga mengemukakan bahwa citra merekmemiliki dampak yang positif terhadap niat membeli konsumen.Penelitian oleh Maunaza (2012) dan Shah et al.(2012) mengatakan bahwa citra merek memiliki pengaruh positif yang signifikan terhadap niat beli konsumen. Selain itu, pernyataan tersebut didukung juga oleh hasil penelitian Nan \& Bih (2007) yang menunjukkan adanya pengaruh citra merek terhadap niat beli. 
Pengujian hipotesis pada peran citra merek dalam memediasi pengaruh kualitas produk terhadap niat beli produk laptop apple macbook di Kota Denpasar. Ditunjukkan dengan signifikan pada alpha 5 persen ( $p$-value $0,037 \leq 0,05)$. Niat beli akan semakin tinggi lagi, jika kualitas produk juga mampu meningkatkan citra merek. Berdasarkan hal tersebut maka hipotesis kualitas produkberpengaruh signifikan terhadap niat beli produk laptop apple macbook di Kota Denpasarmediasi oleh citra merek diterima. Hasil penelitian ini sesuai dengan Ruth et al. (2002) menyatakan bahwa sikap terhadap merek tertentu dipengaruhi oleh kesan atau citra dari merek tersebut. Park et al. (1986); dan Juhairi et al. (2006) menyatakan citra merek memiliki pengaruh langsung pada volume penjualan produk. Aaker dan Keller (1990); Putra dan Sulistyawati (2015); dam Kirwadi (2016) meyatakan bahwa semakin baik citra merek maka akan semakin tinggi niat beli konsumen.

Implikasi hasil penelitian ini dibagi menjadi 2 yaitu implikasi teoritis dan implikasi praktis. Secara teoritis hasil temuan penelitian ini memperkuat penelitian-penelitian sebelumnya yang menunjukkan bahwa kualitas produk dan citra merek dapat mempengaruhi niat beli serta citra merek dapat memediasi kualitas produk terhadap niat beli.

Secara praktis variabel-variabel dalam penelitian ini yaitu variabel kualitas produk, dan citra merek berpengaruh positif dan signifikan terhadap niat beli produk Apple macbook di Kota Denpasar serta citra merek mampu memediasi kualitas produk terhadap niat beli produk Apple macbook di Kota Denpasar. Untuk variabel kualitas produk, Apple sebagai perusahaan yang memproduksi 
laptop Apple macbook selalu meningkatkan kualitas produk yang dimilikinya, dengan meningkatkan kualitas produk Apple macbook maka dapat menambahkan daya beli yang dimilikinya serta dapat meningkatkan citra merek Apple macbook yang dapat mempengaruhi niat beli konsumen. Kualitas produk yang baik dapat mempengaruhi niat konsumen untuk membeli produk Apple macbook bila mampu memenuhi kebutuhan yang diinginkan oleh konsumen.

Variabel citra merek adalah variabel yang perlu diperhatikan oleh Apple karena dapat mempengaruhi niat beli dan memediasi kualitas produk terhadap niat beli. Apple perlu menjaga dan meningkatkan citra merek yang dimiliki produk Apple macbook agar memiliki kesan yang baik di benak konsumen, sehingga konsumen merasa yakin dan memiliki niat untuk membeli produk Apple macbook. Ketiga variabel yang diteliti memiliki keterkaitan satu sama lain sehingga Apple sebagai perusahaan yang memproduksi Apple Macbook perlu meningkatkan kualitas produknya serta tetap menjaga citra merek agar kesan yang tertanam di benak konsumen tetap baik dan agar dapat mempengaruhi niat konsumen untuk membeli produk Apple macbook.

Berdasarkan penelitian yang telah dilakukan, terdapat beberapa hal yang menjadi keterbatasan di dalam penelitian ini. Adapun keterbatasan yang dapat diuraikan, yaitu ruang lingkup penelitian ini hanya pada konsumen yang berada di Denpasar,sehingga penelitian ini tidak dapat digeneralisasi untuk konsumen di luar kota Denpasar. Ukuran sampel yang digunakan masih terbatas, disisi lain perkembangan jumlah dan karakteristik dari konsumen yang berniat membeli dan 
menggunakan produk laptop apple macbook akan terus berkembang dan semakin luas segmentasinya.

\section{SIMPULAN DAN SARAN}

Berdasarkan hasil pembahasan penelitian yang telah dilakukan, maka dapat disimpulkan bahwa kualitas produk berpengaruh positif dan signifikan terhadap citra merek. Semakin tinggi kualitas produk masyarakat, maka menimbulkan penurunan pada citra merek produk laptop apple macbook di kota Denpasar.

Kualitas produk berpengaruh positif dan signifikan terhadap niat beli. Semakin tinggi kualitas produk masyarakat, maka menimbulkan penurunan pada niat beli produk laptop apple macbook di kota Denpasar.

Citra merekberpengaruh positif dan signifikan terhadap niat beli. Masyarakat yang memiliki citra merek yang tinggi akan membuat niat beli di produk laptop apple macbook di kota denpasar meningkat.

Citra merek memediasi pengaruh kualitas produk terhadap niat beli laptop apple macbook.

Saran yang dapat diberikan berdasarkan kesimpulan yang didapat adalah sebagai berikutperusahaan harus memperhatikan kualitas produk dan citra merek. Apabila laptop Apple macbook memiliki kualitas produk tinggi maka akan dapat meningkatkan citra merek laptop Apple macbook, berdasarkan nilai deskriptif terkecil terdapat pada pertanyaan Produk laptop apple macbook memiliki daya tahan komponen yang baik dibandingkan produk laptop lainnya, berarti hal ini harus diperhatikan oleh produk laptop apple macbook dengan mengembangkan 
daya tahan komponen yang lebih dari produk - produk pesaing produk laptop Apple macbook.Berdasarkan nilai rata-rata terendah pada variabel citra merek di peroleh pada pernyataan produk laptop Apple macbook memiliki penampilan yang menarik dengan model yang tidak ketinggalan jaman dan produk laptop Apple macbook memiliki kualitas produk yang baik dan sudah terbukti aman digunakan. Produk laptop Apple macbook harus mengembangakan desain dari produk-produk laptop yang dimiliki sehingga dapat menarik niat beli konsumen. Dengan meningkatkan niat beli, hal ini sangat penting dalam membangun sebuah perusahaan untuk bersaing kedepannya dengan perusahaan lain atau perusahaan pesaing.

Bagi penelitian selanjutnya diharapkan mampu menambah variabelvariabel yang dapat mempengaruhi niat beli, dan mampu untuk memperluas ruang lingkup penelitian yang tidak hanya terbatas pada satu lokasi penelitian atau suatu produk yaitu produk laptop Apple macbook di kota denpasar, sehingga memberikan suatu pandangan yang lebih dan mampu diimplementasikan secara umum.

\section{REFERENSI}

Aaker, D.A., and Keller, K.L. (1990). Consumer Evaluations of Brand Extensions. Journal of Marketing, 54 (1), pp. 27-41.

Annafik, A.F dan M. Rahardjo. (2012). Analisis Pengaruh Kualitas Produk,Harga. Dan Daya Tarik Iklan Terhadap Niat Beli Sepeda Motor Yamaha (Studi Kasus Pada Konsumen Yamaha Ss Cabang Kedungmundu Semarang). Journal Of Management. 1(2), h:274-281

Belic, Sandra and Emelie Jonsson. (2012). Guerilla Marketing ( And its effects on Consumer Behavior). Sweden : Kristiantad University, School of Healty and Sociaty.

Budiningtyas, Fitria Sari. Didik Purwadi dan Ahmad Mardalis. (2010). 
Faktor-Faktor yang Mempengaruhi Minat Beli Konsumen pada Minimarket. Jurnal Ekonomi Manajemen Sumber Daya, 11(2), pp: 87-107.

Chi Dr.Hsin Kuang, Dr. Huery Ren Yeh, Ya Ting Yang. (2009). The Impact of Brand Awarenees on Consumer Purchase Intention: The Mediating Effect Of Perceived Quality and Brand Loyality. The Journal Of International Managemen Studies. Vol 4, No.1. hh: 135-143

Chinomona, Richard. (2016). Brand Communication, Brand imageand Brand Trust as antecedents of Brand Loyalty in Gauteng Province of South Africa. African Journal of Economic and Management Studies, 7 (1), pp: 124-139.

Dai,Bo, Sandra Forsythe, dan Wi-Suk Kwon. (2014). The Impact Of Online Shopping Experience On Risk Perceptions And Online Purchase Intention: Does Product Category Matter ?.Journal of Electronic Commerce Research, 15 (1).

Dama, Daniel. (2016). Analisis Faktor-faktor yang Mempengaruhi Minat Beli Konsumen Dalam Memilih Laptop Acer di Toko Lestari Komputer Manado. Jurnal Berkala Ilmiah Efisiensi, 16 (01), h:503-514.

Evelina, Nela., Handoyo DW, Sari Listyorini (2013). Pengaruh Citra Merek, Kualitas Produk, Harga, dan Promosi Terhadap Keputusan Pembelian Kartu Perdana Telkom Flexi (Studi Kasus pada Konsumen Telkom Flexi di Kecamatan Kota Kudus Kabupaten Kudus). Jurnal Ilmu Administrasi Bisnis, 1(1),pp : 203-213.

Ghozali, I. (2011). Structural Equation Modelling Metode Alternatif dengan Partial Least Square (PLS) Edisi 3. Semarang: Badan Penerbit Universitas Diponegoro.

Hartini, S. (2012). Perilaku Pembelian Smartphone: Analisis Brand Equity dan Brand Attchment, Journal of Service Marketing, 24 (3): pp : 230-243.

He, Meixian, Zhenquan, band Yuanyuan Yang.(2013). an Empirical Study On Impact Of Brand Image Of Travel Agencies On Customer Purchase Intentions.jurnal. Atlantis Press, Paris, France.

Haerudin, Heri. (2010). Pengaruh Citra Merek Sepeda Motor Honda Terhadap Minat Beli Konsumen. Skripsi. Program Studi Manajemen Fakultas Ekonomi Universitas Pasundan,Bandung.

Indrayani, Linda. (2013). Peran Persepsi Kualitas Produk Dalam Memediasi Pengaruh Gaya Hidup Terhadap Niat Beli Handphone Samsung Galaxy di Kota Denpasar. 
Keller, Kevin lane. (2008). Strategic Brand Management: Building, Measuring and Management Brand Equity $3^{\text {rd }}$ Edition. Upper Saddle River, NJ: Prentince Hall.

Kirwadi. (2016). Pengaruh Perceived Ease of Use Perceived Usefulness Brand Image dan Trust terhadap Purchase Intention Produk Attack Jaz 1 Semerbak Cinta di Kecamatan Kotagede Yogyakarta. Jurnal Manajemen, 6 (1), pp: 4962.

Kiswalini A (2014). Pengaruh Celebrity Endorse, Brand Image dan Kepercayaan Konsumen Terhadap Keputusan Pembelian Sepeda Motor Honda Vario. Skripsi. Sarjana Jurusan Manajemen Pemasaran pada Fakultas Ekonomi dan Bisnis Universitas Udayana, Denpasar.

Kotler, Philip., Amstrong, Gary (2010). Principles of Marketing. $13^{\text {th }}$ Edition. Pearson Education, New Jersey .

Laksana, Fajar. (2008). Manajemen Pemasaran. Edisi 1. Yogyakarta : Graha Ilmu.

Maunaza, A. (2012). "Pengaruh Brand image terhadap Niat Membeli Konsumen (Studi Pada Penerbangan Lion Air Sebagai Low Cost Carrier)". Skripsi Fakultas Ilmu Sosial Dan Ilmu Politik Program Studi Ilmu Administradi Niaga Depok.

Nan Hon Lin., \& Bih Shya Lin. (2007). The effect of brand image and product knowledge on purchase intention moderated by price discount. Journal of International Management Studies. 2(2),pp:121-132.

Nuraini, Alfiyah, dan Ida Maftukhah. (2015). Pengaruh Celebrity Endorse dan Kualitas Produk Terhadap Keputusan Pembelian Melalui Citra Merek Pada Kosmetik Wardah di Kota Semarang. Management Analysis Journal, 4 (2), h. 2252-6552.

Nurdianto, Dedi, dan Tri Yuniati. (2013). Pengaruh Kualitas Produk dan Citra Sebagai Variabel Intervening terhadap Keputusan Konsumen dalam Membeli Motor Honda. Jurnal Ilmiah dan Riset Manajemen, 2 (10), h. 1-29.

Noerchoidah. (2013). Analisis Pengaruh Harga,Kualitas Produk dan Iklan terhadap Brand Image dan Keputusan Pembelian Sepeda Motor Merek Kawasaki. Jurnal WIGA, 3 (1), h. 2088-0944.

Park, C.W., Jaworski, B.J., and Maclnnis, D.J. (1986). Strategic Brand ConceptImage Management. Journal of Marketing, 50 (4), pp : 135-145. 
Pradipta, Dyah Ayu Anisha, (2012). Pengaruh Citra Merek (Brand Image) Terhadap Loyalitas Konsumen Produk Oli Pelumas PT. Pertamina (Persero) Enduro 4T di Makassar. Skripsi. Fakultas Ekonomi dan Bisnis Universitas Hasanuddin, Makassar.

Prasetyo, Priyono Puji. (2015). Decission Support System (DSS) Dalam Auditing:Untuk Apa Digunakan ?.Jurnal Akuntansi dan Investasi, 1 (2), h: 62-67.

Putra. I Made Satya Mardhiastina dan I.G.A Ketut Giantari, (2013). Pengaruh Brand Image, Celebrity Endorser ,Kualitas produk dan Kewajaran Harga Terhadap Niat Beli Sepeda motor Matic merek HondadiKota Denpasar.Jurnal Universitas Udayana. 1(1), h: 2869 - 2886

Putra, I K.T.D., and Sulistyawati, E. (2015). Peran Brand Image dalam memediasi Pengaruh Celebrity Endorser terhadap Niat Beli. E-Jurnal Manajemen Unud,4 (6), pp: 1722-1734.

Riduwan dan Engkos Achmad Kuncoro. (2011). Cara Menggunakan dan Memakai Path Analysis (analisis jalur). Bandung : Alfabeta

Sekaran, Uma. (2003). Research Metods For Business. New Jersey : Jhon Willey $\&$

Sons Inc.

Semuel, Hatane dan Elianto Wijaya. (2008). Corporate Social Responsibility, Purchase Intention and Corporate Image pada Restoran Surabaya dari Perspektif Pelanggan. Jurnal manajemen Pemasaran. Vol. 3. No. 1 pp. 3354

Shah, S. S. H., J. Aziz, A. R. Jaffari, S. Waris, W. Ejaz, M. Fatima, K. Sherazi. (2012). "The Impact of Brands on Consumer Purchase intentions".Asian Journal of Business Management 4(2), pp: 105-110.

Sugiyono.(2014). Metode Penelitian Kuantitatif Kualitatif \& RND. Bandung : Alfabeta

Suyanto, Asep Herman. (2015). Perkembangan Komputer. Jurnal komputer, h:13.

Tjiptono, Fandy. (2005), Startegi Pemasaran, Edisi Kedua, Yogyakarta: Penerbit Andi

Wu,P.C.S., G.Y.Y.Yeh., and C.R Hsiao. (2011). The Effect of Store image and Service Quality on Brand and Purchase Intention for Privat Label Brand. Australasian Marketing Journal, 19, pp: 30-39. 
E-Jurnal Manajemen, Vol. 8, No. 1, 2019: 7371 - 7398

Wu, Shwu-Ing and Wen-Hsuan Wanf. (2014). Impact of CSR Perception on Brand Image, Brand Attitude and Buying Willingness: A Study of a Global Café, International Journal of Marketing Studies, 6(6). pp: 43-56

WwW.winpoin.com.2015. 